\title{
PENGOBATAN DAN OBAT TRADISIONAL SUKU SASAK DI LOMBOK
}

\author{
M. Yamin ${ }^{1}$, Burhanudin ${ }^{1}$, Jamaluddin ${ }^{1}$, Nasruddin ${ }^{1}$ \\ ${ }^{1}$ Dosen Program Studi Pendidikan Biologi FKIP Universitas Mataram \\ Email : m.yamin@gmail.com
}

Diterima: 20 Januari 2018. Disetujui: 28 Maret 2018. Dipublikasikan: 14 Mei 2018

\begin{abstract}
Abstrak
Riset ini secara keseluruhan mengikuti kerangka kerja bidang linguistis-antropologis, kimia, dan biologi. Pada tahun pertama telah dilakukan kajian linguistis-antropologis. Kajiannya mencakup kegiatan identifikasi bentuk teks pengobatan tradisional Sasak dalam naskah lontar Usada, transliterasi teks Usada ke dalam Bahasa Indonesia, identifikasi jenis pengobatan tradisional dari isi naskah dan informasi masyarakat Sasak di Lombok, serta teknik pengobatan tradisional Sasak masing-masing jenis pengobatan dimaksud. Hasil inventarisasi jenis penyakit dari lima naskah lontar Usada, tercatat 324 jenis penyakit, namun setelah ditabulasi dan dibandingkan antara terjemahan naskah satu dengan naskah yang lain diperoleh sebanyak 263 jenis penyakit. Sisanya 61 jenis penyakit tertulis pada lebih dari satu naskah. Adapun tumbuhan obat/bahan obat dari naskah lontar Usada tersebut dan informasi dari masyarakat tercatat 163 jenis. Beberapa jenis merupakan tumbuhan obat/bahan obat unggulan nasional, khas, mulai langka, dan tercatat 63 nama tumbuhan $(38,6 \%)$ belum diketahui nama nasionalnya. Adapun yang berasal dari hewan yang digunakan sebagai obat/bahan obat tradisional oleh masyarakat Sasak sebanyak 11 jenis hewan seperti kerang untuk penyakit kuning, daging burung koak kao untuk obat pintar, dan madu untuk lemah sahwat, luka bakar dan jerawat. Teknik pengobatan tradisional Sasak dilakukan dengan cara: bahan-bahannya digiling, dikunyah, ditumbuk, diperas, dicampur, dibakar dan diparut, direbus, dimasukkan dalam wadah tertentu, diisi air, dibakar, dan diremas. Selain itu, juga dengan cara dilulur, dioles, disemburkan, ditempel, diusap, ditetes, digosok, diminum, dibalur, dibilas, diurap, dan ditambal.
\end{abstract}

Kata kunci : Pengobatan, Obat, tradisional

\begin{abstract}
This research as whole follows frameworks in anthropological linguistics, chemistry, and biology. In the first year, the research full into anthriopological and linguistics. The study include : the form of texts on Sasak medicinal found on "Usada" tranliteration of the Usada texts into Indonesian, identification of the types of traditional medicinal at contained within Sasak traditional texts and information provided by the Sasak community in Lombok and identification techniques for each medicinal from the five Usada texts, the writer fond that 324 kinds of desease, but after tabulation and comparasion translated text, it was fond that there were 263 kinds of desease. The rest, 61 kinds of deseases, were fond in more 163 plants used as medicine from those names, there were 63 plants name (38\%) knowm only Sasak language and still unknown in Indonesia name. Other names were known to be medicinal and national level, local species, endemic, and beginning to be endangered. From animal products, there were 11 animal names mentioned to be substances in traditional medicines. There names included seashell for hepatitis, the flesh of Philemon buceroides for brain energizer, and honey for premature ejeculation, burnts, and pimples medication tecknique in Sasak tradition could be done in number of ways as the materials are ground munched, pounded pressed, mixed, burnt and groundes, boiled, placed in certain container with hands. Other ways include molesting applying, sprouting, sticking wiping,dropping, bolming, dringking, washing,and maxing.
\end{abstract}

Key words : medicinal, medicines,traditional 


\section{PENDAHULUAN}

Kesehatan sebagai salah satu kebutuhan dasar manusia memiliki peran strategis bagi upaya peningkatan kesejahteraan manusia. Hubungan antara keduanya berbanding lurus, yaitu makin tinggi tingkat kesehatan suatu masyarakat maka makin meningkat kesejahteraannya, dan sebaliknya. Masalah kesehatan adalah masalah yang kompleks tidak hanya menyangkut persoalan medis dan teknis semata tetapi juga menyangkut persoalan budaya, pendidikan masyarakat, luas dan topografi wilayah, jumlah penduduk, pendapatan masyarakat, dan sebagainya. Misalnya, tradisi penanganan kesehatan yang bersifat tradisional dengan menggunakan tradisional spesies, yaitu beberapa spesies tumbuhan atau hewan yang diketahui secara turun temurun mempunyai khasiat mengobati masih populer di masyarakat. Hal ini dilakukan mengingat upaya ini relatif murah, mudah, dan merupakan peninggalan nenek moyang, sehingga keberterimaan masyarakat tinggi, selain didukung oleh potensi alam kita yang memiliki berbagai tumbuhan dan hewan yang berkhasiat obat atau pergi ke dukun. Cara ini dilakukan turun temurun dengan menggunakan bahan alam baik tumbuhan maupun hewan yang berkhasiat mengobati yang terdapat di sekitar mereka.

Mengingat
kempleksnya
permasalahan kesehatan masyarakat
maka perlu ada upaya terpadu yang
relevan dan dimungkinkan untuk
diimplementasikan sebagai bentuk
proteksi dini terhadap penanganan
kesehatan masyarakat. Artinya,
diperlukan adanya pemikiran dan

tindakan yang berorientasi kepada penanganan terhadap kesehatan baik dalam penyediaan informasi maupun pengembangan teknologi bagi penanganan masalah kesehatan masyarakat. Misalnya, tradisi penanganan kesehatan yang bersifat tradisional dan atau dengan menggunakan tradisional spesies, yaitu beberapa spesies tumbuhan atau hewan yang diketahui secara turun temurun mempunyai khasiat mengobati. Sekitar 30.000 spesies tumbuhan berbunga terdapat di hutan tropik Indonesia, dan tidak kurang dari 1650 spesies memiliki khasiat sebagai obat (Burkill, 129 : 65). Dalam hubungan ini, sejumlah pengobatan tradsisonal Suku Sasak terlihat lebih efektif daripada yang lazim digunakan dokter; demikian pula halnya dengan obat-obatannya nampaknya lebih mujarab daripada obat kimia (moderen), misalnya dalam penanganan wanita hamil dan obat kontrasepsi. Pengetahuan masyarakat tradisional Suku Sasak mengenai pengobatan itu diwarisi turun temurun dari nenek moyang dan atau dari naskah lontar Lombok yang telah berusia lebih ratusan tahun. Naskah itu, sebagian besar telah rusak, hanya beberapa masih tersimpan di Museum Negeri Mataram dan masyarakat. Sejauh ini, kajian mengenai pengobatan dan obat-obatan dari pengetahuan dan pengalaman empiris masyarakat tradisional Sasak masih sangat sedikit, dan dari isi naskah lontar Lombok belum pernah dilakukan, padahal naskah itu tidak lama lagi akan musnah dimakan usia.

Dari uraian di atas, perlu diidentifikasi bentuk teks yang menyimpan ihwal pengobatan tradisional masyarakat Sasak, bentuk pengobatan 
tradisional masyarakat Sasak yang terdapat dalam naskah/teks, bahan masing-masing jenis pengobatan, dan teknik pengobatan masing-masing jenis pengobatan tradisional dimaksud. Selanjutnya, dilakukan proses pengujian ilmiah secara kimiawi tentang unsur yang terdapat dalam bahan dari masing-masing jenis pengobatan tradisional masyarakat Sasak. Pada tahap akhir dilakukan upaya pelestarian (konservasi) bagi bahan obat terutama yang berasal dari alam seperti tumbuh-tumbuhan dengan melakukan kajian tentang habitat/tempat tumbuh. Tujuannya, selain untuk menyediakan informasi dan pengembangan teknik penanganan masalah kesehatan, dan obatobatan, juga sebagai upaya konservasi naskah lontar Lombok, budaya, obat/bahan obat bagi masyarakat. Hasilnya akan bermanfaat bagi pengembangan teknologi kesehatan (pengobatan) dan tambahan penyediaan informasi mengenai pengobatan dan obat-obatan dalam upaya meningkatkan kesehatan dan kesejahteraan masyarakat. Pada tahap pertama ini kajian difokuskan pada kajian yang sifatnya linguistis antropologis untuk mengetahui : bentuk teks atau naskah yang memuat bentuk pengobatan tradisional dalam masyarakat Sasak;mentransliterasi teks atau naskah pengobatan tradisional dalam masyarakat Sasak dalam Bahasa Indonesia; mengetahui jenis pengobatan tradisional Sasak yang terdapat dalam naskah/teks; mengetahui bentuk bahan-bahan yang digunakan dalam masing-masing jenis pengobatan tradisional masyarakat Sasak yang terdapat dalam teks tersebut; mengetahui teknik atau proses pengobatan dari masing-masing jenis pengobatan tradisional masyarakat Sasak yang terdapat dalam teks tersebut; mengetahui bentuk unsure kimia (bioaktif) yang terdapat dalam masingmasing bahan pada masing-masing jenis pengobatan tradisional masyarakat Sasak tersebut; danmengetahui upaya pelestarian (konservasi) bahan pengobatan tradisional masyarakat Sasak yang terdapat dalam teks atau naskah tersebut.

\section{METODE PENELITIAN}

Penelitian ini difokuskan pada kajian yang sifatnya linguistisantropologis, yaitu identifikasi teks pengobatan baik yang terdapat dalam naskah maupun dari hasil wawancara mendalam; transliterasi teks pengobatan ke dalam Bahasa Indonesia; identifikasi bentuk pengobatan tradisional Sasak; identifikasi bahan pengobatan dari masing-masing jenis pengobatan; dan identifikasi cara pengobatan tradisional Sasak.

Untuk memperoleh data tersebut di atas telah dilakukan survei terhadap naskah lontar yang diasumsikan berisi tentang pengobatan dan dilakukan wawacara mendalam terhadap terhadap pengobat tradisional (dukun) Sasak serta nama dan tempat pemilik naskah lontar Lombok. Selanjutnya, informasi tentang pengobatan dimaksud ditransliterasi untuk kemudian diklasifikasi berdasarkan jenis pengobatan, bahan pengobatan, dan teknik pengobatan untuk masing-masing jenis pengobatan. Setelah pengklasifikasian, dilakukan pendeskripsian tentang masing-masing aspek tersebut di atas. Jadi, pada tahap pertama kajian difokuskan pada identifikasi bentuk naskah pengobatan tradisional Sasak, kemudian 
ditransliterasi ke dalam bahasa Sasak. Tahap kedua adalah penerjemahan naskah hasil transliterasi Bahasa Sasak ke dalam Bahasa Indonesia. Tahap ketiga adalah identifikasi jenis pengobatan yang terdapat pada masyarakat Sasak berdasarkan data/informasi yang telah dikumpulkan. Tahap keempat adalah pengklasifikasian bahan-bahan pengobatan untuk masing-masing jenis pengobatan. Dan tahap kelima identifikasi teknik pengobatan tradisional Sasak yang mencakup cara pembuatan bahan dan cara pengobatannya.

\section{HASIL DAN PEMBAHASAN}

Riset ini merupakan riset lintas bidang ilmu yang mengkombinasikan kajian linguistik-antropologi, biologi, dan kimia. Pada tahap pertama ini riset diarahkan pada kajian linguistisantropologi. Kajian yang sifatnya linguistik-antropologis terhadap obat tradisional Suku Sasak difokuskan pada identifikasi bentuk teks pengobatan tradisional Suku Sasak yang dikumpulkan dari naskah lontar Usada dan informasi lisan dari masyarakat Suku Sasak. Proses pengumpulan data ini difokuskan pada kajian naskah lontar Usada dan wawancara mendalam (dept interview) terhadap dukun atau tokoh masyarakat Sasak yang memiliki pengetahuan tentang pengobatan tradisional Sasak. Jadi, pada tahap pertama kajian difokuskan pada identifikasi bentuk teks pengobatan tradisional Sasak, kemudian ditransliterasi ke dalam bahasa Sasak. Tahap kedua adalah penerjemahan naskah hasil transliterasi Bahasa naskah (Bahasa Sasak, Bali, Jawa atau Kawi) ke dalam Bahasa Indonesia. Tahap ketiga adalah identifikasi jenis pengobatan yang terdapat pada masyarakat Sasak berdasarkan data/informasi yang telah dikumpulkan. Tahap keempat adalah pengklasifikasian bahan-bahan pengobatan untuk masing-masing jenis pengobatan. Dan tahap kelima identifikasi teknik pengobatan tradisional Sasak yang mencakup cara pembuatan bahan dan cara pengobatannya.

Teks dalam naskah-naskah lontar Usada tertulis dalam Bahasa Sasak, Jawa kuno, Bali, atau campuran ketiga Bahasa teresbut (Bahasa Kawi). Bentuk teks pengobatan tersebut kemudian ditransliterasi ke dalam bahasa Sasak dengan hurup Latin. Selanjutnya isi teks yang sudah ditransliterasi diklasifikasi berdasarkan obat/bahan obat yang digunakan untuk menyembuhkan penyakit dan teknik pengobatan.

Hasil pengumpulan data yang telah dilakukan baik dari dokumentasi berupa naskah lontar yang didapatkan dari indivual dan milik pemerintah (Museum) maupun hasil wawancara dengan para tabib atau dukun Sasak, ditemukan sedikitnya 10 bentuk teks pengobatan. Berikut disajikan contoh masing-masing satu bentuk teks pengobatan tradisional Sasak yang ditulis dalam hurup Latin.

\section{Bentuk teks kelompok satu}

$\mathrm{Ne}$ tumpun sakit otak, matene maraqna teorek, babak boroq teorek siq.

Ne tumpun tengel otak kelemaq, matene mele tidem dowang, pucuk kesambiq telu pucuk taliq siq benang bideng, sedaq jae telu leweng, siq peru otakna. 


\section{Bentuk teks kelompok dua}

$\mathrm{Ne}$ tumpun sakit mate, aiq apuh siq meneng siq beseraup.

$\mathrm{Ne}$ tumpun panas sakit mate, akah lembain teperas tipaq telaweq jari pijerne.

$\mathrm{Ne}$ tumpun tau mate belehna, tunggaq kayuq busur si leq tengaq langan teperading sedaq jae, tepamak.

\section{Bentuk teks kelompok tiga}

$\mathrm{Ne}$ tumpun psakit tian, peno belabur, akah lege siq leq aiq, sedaq sekuh adas, batu

beras pang putih.

$\mathrm{Ne}$ tumpun panas dalam, akah gedang rante, lumut batu bosok nyiur,jari inem jari rapusna.

\section{Bentuk teks kelompok empat}

Ne tumpun silu, akah terong pedar, sedaq sekuh adas, beras pane putih.

Ne tumpun kepaq atawe kepek, sebiye tandan teperading, aiq siq julaq lanjari rapusne.

\section{Bentuk teks kelompok lima}

Ne tumpun batuq siq sugul daraq leman bewehna, kunyit warangan, aiq jeruk ileng jari inem.

Ne rumpun batuk, akah re, tengaq lengan, tebau 7 akah, 7 buku taliq aiq benang bideng 7 leyot, katik cengkeh 7 jae 7 leweng gule ye tekelaq iye jari.

\section{Bentuk teks kelompok keenam}

Ne tumpun selamaq, si merisiq kembang prapah, jeluwaq batu, sebiye bangli moto kelap jari rapusne, jari kemalikne teloq, antap ijo.
Ne tumpun selamaq, daun kelor beyaq sepelapaq, besi pasak, sebiye bangli apuh sino gililq jari osoqna malik aiq jari aiq inemna, daun pauq sedaq gule sar, isin rong, banjur kelaq.

\section{Bentuk teks kelompok tujuh}

Tambe gigi ijuk, buwaq baruq tipakq bemayang sedaq mayang nyiur ijo beruq tipaq bemayang ye teanget sedaq sekuh adas.

$\mathrm{Ne}$ wat tiwang kimearanne, ripet gigine, aiq jeruk siq taikin tiyanne tegamul awkne, jari inemne aten bawaq putiq sie aiq jeruk siqne tetaiq.

\section{Bentuk teks kelompok delapan}

Malik lamin panas awakne, oloq awuawu si tegamul tiyanne.

Lamun bebeyaq sakit telih panas, embek, ndeq mauq meleng, pasangan inaq aranne. Jari rapusne isin kordat, anaq puntiqsaq baruq tiwuq, dedaun bokah pituq lembar, tegiliq sedaq sekuuh adas beras pane sengeh jari inemne jari rapus kulit puntiq jawa, seren bukal laiq tundunne jari rapus, sedaq sebiye tandan jae lao.

\section{Bentuk teks kelompok sembilan}

Lamun peneq nanah, jari rapus, jari inem akah bebele saq putiq kembang gamul keng. Lamun karangan akah beberoq perit, akah grateh terupak, sedaq bawang jari loloh.

Ne tumpan baq telor, penyakit ular beleq aranne, babaq lemokeq saq jabut lolone, tegiliq sedaq sekuh adas, wah wah sino daun tekukus tegiliq sedaq jae. 


\section{Bentuk teks kelompok kesepuluh}

Yen tau betian adeqna mudaq sugul anakl, damen inem bulan tamantraq, isiqna tagamul taiyanna, ni mantrana : eh sira say rining kedah manggap lan sira. $\mathrm{Ne}$ siq tatulung tau nganak, serane mamaq teperentaq kaken : mantrana , eh madu mangkubumi mas predi sari, tumurun den agelis. Niq siq tatulung tau nganak, taujutang iya langan balenta bae, yen lanang metuna ta sira mas wali ejim yen wadon matuwa sira mas jerum.
Ne wat sedaq daun kesembong, sedaq lekong bucung isiqna tegamul tiyana urip tasirna malaka. Ne yen tau wah ngamak tan pegat daraqna sugul. Dan palawa bedeng pituq lembar, basana nadas jari rapus, mantrana : mutahala getih ireng muka brang getih abang, mandek tasirna mambas. Yen ndeqna sugul barakna masih iya watna, mantrana tunggal, sok lain tatutuq bae, kena metu t6asina mambas.

Tabel Profil 5 Naskah dari 21 Naskah Usada Koleksi Museum Negeri Mataram Tahun 2006

\begin{tabular}{|c|c|c|c|c|c|c|c|c|}
\hline No & $\begin{array}{c}\text { No. } \\
\text { Naskah }\end{array}$ & $\begin{array}{l}\sum \text { lempir } \\
\text { /halaman }\end{array}$ & Huruf & Bahasa & $\begin{array}{c}\text { Lebar } \\
(\mathrm{cm})\end{array}$ & $\begin{array}{c}\text { Panjang } \\
(\mathrm{cm})\end{array}$ & $\begin{array}{c}\text { Tgl. } \\
\text { koleksi }\end{array}$ & Asal \\
\hline 1 & 07.664 & $5 / 10$ & Jejawen & Kawi & 4,2 & 49 & $4 / 3-1980$ & Lobar \\
\hline 2 & 07.30 & $50 / 100$ & Jejawen & Bali & 2,8 & 40 & 23/6-1976 & Matram \\
\hline 3 & 07.341 & $18 / 36$ & Jejawen & Bali & 4 & 44 & $5 / 12-1978$ & Loteng \\
\hline 4 & 07.663 & $54 / 108$ & Jejawen & Lombok & 2,8 & 10,5 & $24 / 6-1986$ & Lotim \\
\hline 5 & S1 & $56 / 112$ & Jejawen & - & 2,8 & 35 & - & - \\
\hline \multicolumn{5}{|c|}{ Rata-rata } & 3,32 & 35,7 & - & - \\
\hline
\end{tabular}

Hasil inventarisasi penyakit yang ditangani dengan pengobatan tradisional Sasak dari 5 naskah lontar Usada dikelompokan kedalam 12 golongan penyakit yaitu: $\quad$ 1) perut dan ulu hati, 2 kepala, 3) panas dingin, 4) tulang, 5) mata, 6) kulit dan alergi, 7) sariawan, 8) telinga,hidung dan tenggorokan, 9) Reproduksi, 10) gigi dan gusi, 11) kelamin, dan 12) lain-lain seperti darah tinggi, kolesterol, ginjal, dan lain-lain. Adapun jumlah penyakit tercatat 324 jenis, namun setelah ditabulasi dan dibandingkan antara terjemahan naskah satu dengan naskah yang lain diperoleh sebanyak 263 jenis penyakit. Sisanya 61 jenis penyakit tertulis pada lebih dari satu naskah lontar Usada. Penelitian serupa yang dilakukan pada masyarakat Suku Tengger di Kabupaten Lumajang dan Malang Jawa Timur melaporkan, tercatat 26 jenis penyakit yang dikelompokkan dalam 8 kategori penyakit, yaitu penyakit pada mata, penyakit pencernaan, penyakit mulut dan rongga mulut, penyakit pada kulit, penyakit karena infeksi, penyakit karena nyeri,dan penyakit lain-lain pengobatan menggunakan 54 spesies tumbuhan yang tersebar dalam 30 famili (Indah 2016).

Adapun tumbuhan obat/bahan obat dari hasil terjemahan naskah lontar Usada dan informasi dari masyarakat Suku Sasak di Pulau Lombok tercatat 163 jenis. Dari jumlah tersebut tercatat 50 jenis $(30,7 \%)$ belum diketahui jenisnya, 
tidak dapat dilakukan identifikasi karena tidak tercantum ciri-ciri morfologis maupun gambar bahan dalam naskah. Adapun obat/bahan obat yang berasal dari hewan sebanyak 11 jenis (Tabel 2).

Adapun Jenis obat/bahan obat tradisional dalam naskah lontar Usada diperoleh antara lain yaitu: sakit perut dan ulu hati, sakit kepala, sakit panasdingin, sakit tulang, sakit mata, sakit kulit dan alergi, sakit sariawan, sakit telingahidung-tenggorokan, melahirkan-tidak punya anak-kekurangan asi, sakit gigi dan gusi, sakit kelamin, dan lain-lain. Jenis penyakit yang digolongkan dalam kelompok lain-lain misalnya sakit dada, sakit ginjal, luka baker, sesak napas, darah tinggi, dan lain-lain. Bahan pengobatan obat tradisional Sasak umumnya berasal dari bahan alami misalnya kencur, adas, jerami, beras harum, merica, jahe, labu (air), cocor bebek, eceng gondok, banten, asam, bangle, weru, dadap, beringin, gandarusa, lengkuas, jelateng, jeliti, kamboja, jeringo, papaya, kemangi, kenari, kesambi, turi, ketumbar, kunyit (lemu), bayam, lempuyang, pala, dan terung. Selengkapnya seperti dalam Tabel 1.

Teknik pengobatan yang dimaksud mencakup cara pembuatan bahan dan cara pengobatannya. Cara pembuatan obat tradisonal sasak secara umum dilakukan dengan cara bahannya digiling, dikunyah, ditumbuk, diperas, dicampur, dibakar dan diparut, direbus, dimasukkan dalam wadah tertentu, diisi air, dibakar, dan diremas. Adapun cara pengobatannya secara umum dapat dilakukan dengan cara dilulur, dioles, disemburkan, ditempel, diusap, ditetes, digosok, diminum, dibalur, dibilas, diurap, dan ditambal. Sejalan dengan hal ini, Salmen \& Sismudjito (2015) melaporkan bahwa pengobatan tradisional di masyarakat Sumatera Utara dilakukan dengan cara dimimum/makan, dipijat, memamnggil jiwa, mantera, sembur, memakai minyak, menenpelkan ramuan, memakai kuning, mandi uap dan mengolesi.

Pengobatan dan obat/bahan obat tradisional Suku Sasak hasil terjemahan naskah lontar Usada dan informasi masyarakat Suku Sasak di Pulau Lombok potensial dikembangkan sebagai pengoabatan dan obat alternatif. Hal ini didukung oleh beberpa faktor seperti : mudah diperoleh, distribusi habitatnya yang tersebar luas di seluruh daerah Indonesia, ketersediaan bahan yang cukup bahkan beberapa jenis masih melimpah, khasiatnya terlihat efektif, bahkan beberapa jenis obat terlihat lebih mujarab daripada obat kimia (moderen), murah, dan keberterimaan masyarakat khususnya Suku Sasak lebih besar. Selain itu, beberapa jenis diantaranya merupakan tumbuhan obat/bahan obat unggulan nasional, khas daerah dan mulai langka. Adapun obat/bahan obat dimaksud dan khasiat utamanya masing seperti dalam Tabel di bawah ini. 
Tabel 1. Tumbuhan dalam naskah lontar Usada dan informasi masyarakat yang digunakan sebagai obat/bahan obat tradisional Suku Sasak di Pulau Lombok

\begin{tabular}{|c|c|c|c|}
\hline \multirow[t]{2}{*}{ No } & \multicolumn{2}{|c|}{ Nama Tumbuhan } & \multirow[t]{2}{*}{ Khasiat utama } \\
\hline & Indonesia/lokal & Latin & \\
\hline 1. & Acar & Antiaris toxicaria & Desentri, panas \\
\hline 2. & Adas & Funiculum vulgare & Sakit perut, desentri, panas \\
\hline 3. & Anggur & Vitis vinifera & Kudis \\
\hline 4. & Andus & & Penghalus kulit bayi \\
\hline 5. & Antak antak & & Dingin menggigil \\
\hline 6. & Api-api & Avicennia officinalis & Cacar \\
\hline 7. & Aru & & Kontrasepsi, kolesterol \\
\hline 8. & Asam & Tamarindus indica & Dingin menggigil, sakit mata \\
\hline $\begin{array}{l}9 . \\
10 .\end{array}$ & $\begin{array}{l}\text { Ati beru } \\
\text { Ayan/kelicung }\end{array}$ & Diospyrus vilaria & $\begin{array}{l}\text { Tiwang dan alergi } \\
\text { Hernia "borot" }\end{array}$ \\
\hline 11. & Alang-alang & Imperata cilindrica & Panas dan kencing batu, spilis \\
\hline 12. & Apung -apung & & Silu \\
\hline 13. & Arak & Ficus septica & Panas, bengkak \\
\hline 14. & Bambu & Bambusa sp. & Rematik dan sakit mata \\
\hline 15. & Banten & A. grandiflora & Rematik dan bisul \\
\hline 16. & Babele & Aegle marmelos (L.) Correa & Kencing nanah, gondok \\
\hline 17. & Barekda & & Koreng \\
\hline 18. & Barora & Klemhovia hespita & Sariawan \\
\hline 19. & Bawang merah & Allium sativum & eksim, muntaber, tiwang \\
\hline 20. & Bayam & Amaranthus $\mathrm{sp}$ & Tiwang, eksim \\
\hline 21. & Bantenu & Mellochia umbellata & Penambal sakit lengkang \\
\hline 22. & Beringin & Ficus sp. & Kerm \\
\hline 23. & Bengkel & Nauclea speciosa & Silu \\
\hline 24. & Beru & & Tiwang \\
\hline 25. & Bilola & & Sariawan \\
\hline 26. & Bidara putih & Merremia sp. & Cuci darah \\
\hline 27. & Belimbing wulu & Averrhea bilimbi & Bisul, rematik \\
\hline 28. & Bikan & & Gusi berdarah \\
\hline 29. & Birak & Eichhornia sp. & Tiwang \\
\hline 30. & Brotowali & Tinospora arispa & Kolesterol, gatal-gatal, malaria \\
\hline 31. & Bunga sepatu & Hibiscus rosa-sinensis & Panas \\
\hline 32. & Cabe hutan & Piper retrofractum & Dingin, silu-silu dan pegal linu \\
\hline 33. & Cemara & Casuarina trifolia & Kulit bersissik \\
\hline 34. & Ceugtali & & Tiwang \\
\hline 35. & Cocor bebek & Kalanchoe pinnata. & Panas \\
\hline 36. & Dadap & Erythrina lithosperma & Kencing batu \\
\hline 37. & Daun Dewa & Gynura procumbens & Koleterol \\
\hline 38. & Darah biru & & Amandel \\
\hline 39. & Daun sendok & Plantago mayor & Keputihan \\
\hline 40. & Delima & Punica granatum & Cacar, berak darah, sakit mata \\
\hline 41. & Enceng gondok & Eichhornia crassipes & Vagina gatal, keputihan \\
\hline 42. & Empet-empet & Daun digiling & $\begin{array}{l}\text { Desentri,menghentikan pendarahan, } \\
\text { antibiotik, luka }\end{array}$ \\
\hline 43. & Entut-entut & Paederia foetida $\mathrm{L}$. & Sakit perut, sakit pinggang \\
\hline 44. & Gambir & Uncaria gambir & Desentri \\
\hline 45. & Ganda rusa & Justica gandarussa & Kencing batu, panas dalam \\
\hline 46. & Gegarit & & Punya anak, keram, raja singa \\
\hline 47. & Gelumpang & & Infeksi, borok \\
\hline 48. & Grepek & Erythrina sp. & Cacar \\
\hline 49. & Ice jambiq & & Silu \\
\hline 50. & Inggu & Ferula asa-foetida & Sakit kepala sebela \\
\hline 51. & Inja biteq & & Saraf \\
\hline
\end{tabular}




\begin{tabular}{|c|c|c|c|}
\hline 52. & Isi buyah & & Tiwang \\
\hline 53. & Jarak pagar & Jatropha curcas & Mimisan, menceret, panas \\
\hline 54. & Jambu biji & Psidium quajava & Bau badan, sakit perut, tumor, malaria, \\
\hline 55. & Jahe & Zingiber officinale & Silu, sakit perut, rematik \\
\hline 56. & Jelatang & Toxicodendron radicans & Gatal-gatal, sakit gubuk \\
\hline 57. & Jejangkah & & Sakit kepala, panas \\
\hline 58. & Jejang & & Sakit kepala, panas \\
\hline 59. & Jeruk nipis & Citrus aurantifolia & Demam, batuk \\
\hline 60. & Jeringo & Acorus calamus & Sakit perut, silu \\
\hline 61. & Jeliti & Wrightia javanica & Rematik \\
\hline 62. & Jilawal & & Sakit kepala, panas \\
\hline 63. & Jowet & Eugenia cumini & Skit perut, desentri, silu, borok \\
\hline 64. & Joban & & Alergi \\
\hline 65. & Kacang hijau & Phaseolus mungo & Muntaber \\
\hline 66. & Jepun & Plumiera acuminata & Lemah sahwat \\
\hline 67. & Kanangas & Ximenia sp. & Eksim \\
\hline 68. & Kangkung & Ipomoea eptans & Dingin, rabun, tiwang, kulit \\
\hline 69. & Kalogi & & Sakit kepala, panas \\
\hline 70. & Kapas & Gossypium sp. & Luka bakar \\
\hline 71. & Katerep & & Sakit kepala, panas \\
\hline 72. & Katuk/sagar & Saurapus androginus & Sariawan \\
\hline 73. & Kayu wari & & Gatal-gatal \\
\hline 74. & Kecubung & Datura metel & Panas dalam \\
\hline 75. & Kelor & Moringa oleifera & Silu, kencing batu \\
\hline 76. & Kelapa & Cocos nucifera & $\begin{array}{l}\text { Darah tinggi, ginjal, silu, luka, sakit } \\
\text { perut, sariawan }\end{array}$ \\
\hline 77. & Kencur & Kaemeria gelanga & Cacar, desentri, silu, panas \\
\hline 78. & Ketam hitam & Oriza sp. & Panas, silu \\
\hline 79. & Kemuning & Muraya paniculata & Silu, rematik \\
\hline 80. & Kelokos udang & Syzygium sp. & Kulit bersisik \\
\hline 81. & Kantalon & & Menceret \\
\hline 82. & Kumis kucing & Orthosiphon stamineus & Ginjal, kencing manis \\
\hline 83. & Kunyit & Curcuma demostica & Antibiotik, desentri, panas \\
\hline 84. & Kemangi & Marsilea & Sakit telinga sigit \\
\hline 85. & Kemangi monyet & Marsilea crenata & Kencing manis \\
\hline 86. & Kardat & & Sakit kepala, panas \\
\hline 87. & Kemiri & Aleurites moluccana & Desentri, perut kidung nganak \\
\hline 88. & Kesambi & Schleichera oleosa & Pilek menahun, silu, pusing 7 hari, \\
\hline 89. & Ketumbar & Coriandrum sativum & panas \\
\hline 90. & Koya arus & & Panas \\
\hline 91. & Kenanga & Canangium odoratum & Panas \\
\hline 92. & Kentalun & & Menceret \\
\hline 93. & Ketimus & Protium javanicum & Sakit koreng raja \\
\hline 94. & Kopi & Coffea arabica & Luka, tambah tenaga \\
\hline 95. & Lada & Piper nigrum & Kembung, malaria \\
\hline 96. & Lalandep & & Kembung, malaria \\
\hline 97. & Lemoteq & & Kembung, malaria, mules \\
\hline 98. & Lengkuas & Alpinia galanga & Silu, panuh \\
\hline 99. & Lebui & Cajanus cajan & Kencing batu \\
\hline 100. & $\operatorname{Laos}$ & Alpinia javanica & Bisul, panuh \\
\hline 101. & Lemokeq & & Mulas, lumpuh rangan empas, silu \\
\hline 102. & Lego & & Sakit mata \\
\hline 103. & Labu air/siam & Sechium edule & Kembung \\
\hline 104. & Lekong & Aleurites moluccana (L.) & Silu, dingin \\
\hline 105. & Lelentaq & & Tambah tenaga, melahirkan, punya anak \\
\hline 106. & Lawam & & Jakun bengkak \\
\hline 107. & Lelet lani & & Sakit 7 badan kejut \\
\hline
\end{tabular}




\begin{tabular}{|c|c|c|c|}
\hline 108. & Lita & Alstonia scholaris & Mag, silu \\
\hline 109. & Lobak & Raphanus sativus & Melancarkan persalinan \\
\hline 110. & Maja & C. paniculata & Malaria, eksim \\
\hline 111. & Meniran & Phyllanthus niruri & Raja singa, ginjal, kencing manis, eksim \\
\hline 112. & Mangga & Mangifera indica & Silu, \\
\hline 113. & Mentimun & Cucumis sativus & Darah tinggi,ginjal \\
\hline 114. & Merang & Oriza sp. & Mules \\
\hline 115. & Nenas & Ananas comosus & Melancarkan haid \\
\hline 116. & Nunang & & Sakit ulu hati \\
\hline 117. & Pangsa & & Penawar racun \\
\hline 118. & Paria & Momordica charantia & Sakit mata \\
\hline 119. & Pace/peko & Morinda citrifolia & Panas, silu, darah tinggi ambeien/wasir \\
\hline 120. & Pakis & Cycas sp. & Tiwang antu \\
\hline 121. & Pandan & Pandanus tectorius & Saraiawan, kulit \\
\hline 122. & Pepaya & Carica papaya & Malaria, menceret \\
\hline 123. & Pepereg & & Alergi \\
\hline 124. & Perepah & & Sakit kulit \\
\hline 125. & Petai & Parkia speciosa & Borok \\
\hline 126. & Papekat & & Sakit kepala, panas \\
\hline 127. & Pinang & Area catechu & Sakit parang \\
\hline 128. & Pisang susu & Musa sp. & Kolera, sakit perut, penawar racun \\
\hline 129. & Petikan kebo & Euphorbia hiria & Kencing batu, ginjal, mata \\
\hline 130. & Pekinangen & & Sakit kepala, panas \\
\hline 131. & Pemeru & & Desentri \\
\hline 132. & Rebong emat & Bambusa sp. & Diare \\
\hline 133. & Raju mas & Duabanga molucana & Diare \\
\hline 134. & Rambut bile & & Cacingan \\
\hline 135. & Randu & Ceiba pentandra & Karang \\
\hline 136. & Rumput lejang & & Batuk darah \\
\hline 137. & Sambung nyawa & Gynura sarmentosa DC & Kolesterol, pinggang, pusing, \\
\hline 138. & Saladri & A. graveolens. $L$ & Darah tinggi \\
\hline 139. & Salam & Syzygium polyantarum & Pusing, sariawan \\
\hline 140. & Sambiloto & Andrographis paniculata & $\begin{array}{l}\text { Kolesterol, kencing manis, ambaien, } \\
\text { kanker, nafsu makan }\end{array}$ \\
\hline 141. & Segara gunung & & Sakit kepala \\
\hline 142. & Seneg & & Silu \\
\hline 143. & Sanggenit & & Bayi ngorok \\
\hline 144. & Sirih & Piper betle & $\begin{array}{l}\text { Panas, bau mulut, sakit mata, sakit gigi, } \\
\text { keputihan }\end{array}$ \\
\hline 145. & Selasih hitam & Ocimum basilicum L & Panas \\
\hline 146. & Sereto & Ehretia microphyla & Malaria \\
\hline 147. & Srikaya & Annona squamosa & Malaria \\
\hline 148. & Suren & Toona sureni & Bisul \\
\hline 149. & Soka & Ixora paludosa & Panas \\
\hline 150. & Songgo langit & Tridax procumbens & $\begin{array}{l}\text { Sakit pinggang, ginjal, kepala, darah } \\
\text { tinggi, dan kolesterol }\end{array}$ \\
\hline 151. & Tapak dara & Catharanthus receous & Kencing manis \\
\hline 152. & Pecut kuda & Stachytarpheta jamaicensis. & Amandel, bengkak pada kaki \\
\hline 153. & Temu lawak & Curcuma xanthorrhiza & Flu, panas \\
\hline 154. & Tembakau & Nikotiana tobacum & Borok \\
\hline 155. & Terong & Solanum melongena & Rematik, \\
\hline 156. & Terentem & & Bayi panas \\
\hline 157. & Teruti & & Panas \\
\hline 158. & Tebu besi & Saccharum sp. & Anti ubanan \\
\hline 159. & Tetipah & & Panas \\
\hline 160. & Towaq & & Borok \\
\hline 161. & Waru laut & Thespesia populnea & Panas, silu \\
\hline
\end{tabular}




\begin{tabular}{|l|l|l|l|}
\hline 162. & Wortel & Daucus carota & Sakit perut, desentri \\
\hline 163. & Wareng & Gmelina elliptica & Luka bernanah, gusi berdarah \\
\hline
\end{tabular}

Dari tabel di atas, terlihat obat/bahan obat tradisional Suku Sasak potensial dikembangkan penerapannya sebagai pengobatan dan obat alternatif. Hal ini didukung oleh beberapa faktor seperti: ketersediaan bahan, mudah diperoleh karena sebagian besar tumbuh liar, distribusi habitatnya tersebar luas hampir di seluruh daerah Indonesia, beberapa jenis masih melimpah, khasiatnya terlihat cukup efektif bahkan beberapa jenis obat terlihat lebih mujarab daripada obat kimia (moderen), murah, diyakini dampak negatifnya lebih kecil, dan keberterimaan masyarakat khususnya masyarakat Suku Sasak lebih besar. Selain itu, beberapa jenis diantaranya merupakan tumbuhan obat/bahan obat unggulan nasional. Adapun obat/bahan obat tradisional Sasak dari teks naskah lontar Usada seperti terlihat pada Tabel 2 di bawah ini.

Tabel 2. Daftar nama hewan yang digunakan sebagai bahan obat yang termuat dalam naskah lontar Usada dan informasi masyarakat Suku Sasak di Pulau Lombok

\begin{tabular}{|l|l|l|l|}
\hline No & Nama Hewan & \multicolumn{1}{|c|}{ Khasiat } & Bagian yg Dimanfaatkan \\
\hline 1 & Belut & Sakit perut ulu hati & Kepala \\
\hline 2 & Belalang & Sakit kepala & Mata \\
\hline 3 & Burung Koak kao & Kecerdasan/pintrar & Daging \\
\hline 4 & Gurita & Step/kejang-kejang & Tubuh dibakar \\
\hline 5 & Ikan tuna & Rabun mata & Empedu \\
\hline 6 & Kerang & Kuning, kurang tenaga & Isi/ daging tubuh \\
\hline 7 & Kuda & Sakit perut dicengkram & Tulang \\
\hline 8 & Lebah & $\begin{array}{l}\text { Lemah sawat, sakit pnggang, } \\
\text { kulit bersisik, luka bakar, } \\
\text { jerawat }\end{array}$ & Madu \\
\hline 9 & Rayap & Sakit perut, kembung & Sarang \\
\hline 10 & Siput & Bisul pada mata “7 segara" & Tubuh dikunyah \\
\hline 11 & Unggas & Sakit perut & Telur \\
\hline
\end{tabular}

Pemanfaatan hewan sebagai obat/bahan obat tradisional oleh masyarakat Suku Sasak sejalan dengan pemanfaatan obat/bahan obat tersebut saat ini setalah dilakukan analisis kimia dan eksperimen terhadap obat/bahan obat tersebut, misalnya daging burung Koak Kao untuk kecerdasan/pintar, kerang untuk penyakit kuning, dan madu untuk lemah sahwat, luka bakar, dan kulit bersisik. Karena obat/bahan obat tersebut berkhasiat signifikan $\mathrm{Hal}$ ini sangat rasional mengingat kandungan dan fungsi nutrisi yang dikandung oleh obat/bahan obat tersebut berkhasiat seperti diperuntukan tersebut.

\section{KESIMPULAN}

Dari studi dan pembahasan mengenai pengobatan dan obat Tradisional Sasak yang bersumber dari Naskah Lontar Usada dapat disimpulkan:

1. Pengobatan tradisional Sasak dilakukan dengan cara bahanbahannya digiling, dikunyah, ditumbuk, diperas, dicampur, dibakar dan diparut, direbus, dimasukkan dalam wadah tertentu, diisi air, dibakar, dan diremas. Adapun cara 
pengobatannya secara umum dapat dilakukan dengan cara dilulur, dioles, disemburkan, ditempel, diusap, ditetes, digosok, diminum, dibalur, dibilas, diurap, dan ditambal;

2. Obat dan atau bahan obat dalam pengobatan tradisional Sasak menggunakan bahan dari 163 spesies tumbuhan dan 11 spesies hewan.

3. Penyakit yang diobati tercatat 263 jenis penyakit dikategorikan dalam 12 kelompok yaitu sakit: perut dan ulu hati, kepala, panas dingin, tulang, mata, kulit dan alergi, sariawan, telinga,hidung dan tenggorokan, reproduksi, gigi dan gusi, kelamin, dan penyakit lain-lain (darah tinggi, kolesterol, ginjal).

\section{DAFTAR PUSTAKA}

Museum Negeri N T B, 2000. Obatobatan Tradisional Lombok, Departemen Pendidikan Nasioanl Direktorat Jenderal Kebudayaan Museum Negeri Propinsi Nusa Tenggara Barat.

Barber, C.V., Surya Arif, dan Agus Purnomo, 1997. Meluruskan arah pelestarian keanekaragaman hayati dan pembanguanan di Indonesia. Yayasan Obor Indonesia, Jakarta.

Borror, T \& Johnson. 1992. Pengenalan pelajaran serangga. Terjemahan dari Introduction study insect. oleh Suetioyonoparto. S. Gadjah Mada University Press. Yogjakarta.

Ervizal, A., M. Zuhud. 1992. Pelestarian pemanfaatan tumbuhan obat dari hutan tropis Indonesia. Jurusan Konservasi sumber daya Hutan,
Fakultas Kehutanan, Institut Pertanioan Bogor.

Graf, A. B. 1992. Hortica. A color cyclopedia of garden flora in all climates and indoor plants. First edition. Roehrs Company, U.S.A.

Imam Mulyo Suyono. 1991. Studi interaksi masyarakat desa sekitar tumbuhan obat di Taman Nasional Baluran. Jurusan Konservasi sumber daya Hutan, Fakultas Kehutanan, Institut Pertanioan Bogor.

Indah Yulia Ningsih. 2016. Studi etnofarmasi penggunaan tumbuhan obat oleh Suku Tengger di Kabupaten Lumajang dan Malang, Jawa Timur . Pharmacy, Vol.13 No. 01 Juli 2016.

Saifuddin, Abdul Basri, G. Ardiaans, Gulardi hanifa Wknjosastro, dan Djoko Waspodo, 2002. Pelayanan Kesehatan Maternal dan Neonatal, Yayasan Bina Pustaka Sarwono Prawiroharjo, Jakarta.

Salman Sembiring dan Sismudjito. 2015. Pengetahuan dan Pemanfaatan Metode Pengobatan Tradisional pada Masyarakat Desa Suku Nalu Kecamatan Barus Jahe. Jurnal Sosiologi, Volume 3 Nomor 1. Departemen Sosiologi Fakultas Ilmu Sosial dan Politik Universitas Sumatera Utara.

Sastrapradja, D., S. Adisoemarto, K. Kartawinata, S. Sastrapradja \& M.A. $\quad$ Rifai. 1989.

Keanekaragaman hayati untuk kelangsungan hidup Bangsa. Puslitbang Biologi - LIPI, Jakarta.

Sudirman dan Aswandikari, 2003. eksplorasi dan konservasi naskah lontar obat tradisional pada masyaraaakat Sasak di Lombok. Laporan Penelitian. 